\title{
Absolute Isotopic Abundance Ratios and Atomic Weight of a Reference Sample of Strontium
}

\author{
L. J. Moore,* T. J. Murphy,* I. L. Barnes,* and P. J. Paulsen* \\ National Bureau of Standards, Washington, DC 20234
}

July 15,1981

\begin{abstract}
Absolule values have been obtained for the isotopie abundance ratios of a reference sample of strontium using solid sample thermal ionization mass speetrometry. Samples of independently known isolopic eornposition prepared from chemieally pure and nearly isolopieally pure separated strontium isolopes were used to ealibrate

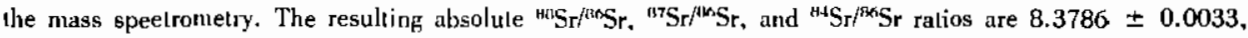
$0.71034 \pm 0.00026$, and $0.05655 \pm 0.00014$ respectively whieh yields atom percenls of: ${ }^{\mathrm{R}} \mathrm{Sr}=82.5845 \pm$ $0.0066,{ }^{\mathrm{B} 7} \mathrm{Sr}=7.0015 \pm 0.0026,{ }^{{ }^{k} \mathrm{~S}} \mathrm{Sr}=9.8566 \pm 0.0034$. and ${ }^{{ }^{4} \mathrm{i}} \mathrm{S} r=0.5574 \pm 0.0015$. The atomie weight caleulated fiom these abundanees is $87.61681 \pm 0.00012$. The indieated uncertainties are overall limits of error based on 95 percent confidence limits for the mean and allowances for the effects of possible systematic error.
\end{abstract}

Key Words: Absolute ratios; alomic weight: isolopic abundances; strontium.

\section{Introduction}

The analytical mass speetrometry group of the National Bureau of Standards is conducting a long term program of absolute abundance ratio and atomie weight determinations on polynuclidic elements using predominantly thermal ionization mass spectrometry though, on occasion, electron impact ionization has been used. Previous elements studied include silver [1], ${ }^{1}$ chlorine [2], copper [3], bromine [4], chromium [5], magnesium [6], lead [7], boron [8], rubidium [9], rhenium [10], silicon [11], potassium [12], and thallium [13]. The present work extends the study to strontium.

Natural strontium consists of four isotopes, ${ }^{88} \mathrm{~S} r,{ }^{87} \mathrm{Sr},{ }^{86} \mathrm{~S} r$, and ${ }^{84} \mathrm{Sr}$. One of thesc, ${ }^{87} \mathrm{Sr}$, is constantly, though slowly, aceumulating as the end product of the decay of ${ }^{37} \mathrm{Rb}$; the other three are believed to be of stable abundance.

The present atomic weight of strontium, 87.62, is based on the relative isotopic measurements of A. O. Nier [14] on a pieee of pure strontium metal. Since this early work there has been no serious effort focused toward the determination of the absolute isotopic abundances of strontium. In the interim, the value of 0.1194 determined by Nier for the ratio ${ }^{86} \mathrm{~S} r{ }^{88} \mathrm{Sr}$ has been nearly universally adopted by the geological community as an interlaboratory standardization value in the mass spectrometric measurement of radiogenic ${ }^{87} \mathrm{Sr}$.

The large limit of error ( \pm 2 percent) associated with Nier's measurement of ${ }^{86} \mathrm{Sr} /{ }^{88} \mathrm{Sr}$ left some uncertainty about a possible systematic error associated with the currently accepted procedure of correcting for instrumental fractionation of the

- Center for Analytical Chemistry, National Measurement Laboralory.

'Figures in brackets indicate literature references at the end of this paper. isotopes by normalizing to Nier's ${ }^{86} \mathrm{Sr} /{ }^{88} \mathrm{Sr}$ ratio $(=0.1194)$. Thus, one primary purpose for the present work was to provide absolute values for the strontium isotopic ratios which might be used as a reference for the hundreds of papers published annually dealing with strontium isotope geology and geochronology.

In the present study the mass spectrometers were calibrated for bias by the use of samples of independently known ${ }^{88} \mathrm{~S}_{\mathbf{r}} /$ ${ }^{80} \mathrm{Sr}$ ratios, prepared from chemically pure and nearly isotopically pure ${ }^{88} \mathrm{~S}_{\mathrm{r}}$ and ${ }^{86} \mathrm{~S}_{\mathrm{r}}$ solutions. These measurcd biases were then used to correct the raw data obtained on a reference sample of strontium thus yielding absolute values for this sample. The reference samplc selected for this work was SRM 987, Strontium Carbonate, which is a highly purified material previously certified for strontium content.

\section{Experimental Procedure}

\subsection{Mass Spectrometry}

Isotopic measurements were performed using a triple filament rhenium jon source. The ionizing filaments used in the measurements were rigorously degassed at $5 \mathrm{~A}(>2000$ $\left.{ }^{\circ} \mathrm{C}\right)$ for $2 \mathrm{~h}$ to reduce any background ion contributions to the ${ }^{86,87,88} \mathrm{Sr}$ mass positions to $<0.01$ percent of the ion beam intensities used in the measurements of the "natural" strontium, SRM 987. The viability of this procedure was supported by scanning these mass positions while heating a "blank" ionizing filament at temperatures in exeess of the usual operating temperature $\left(1600^{\circ} \mathrm{C}\right)$. Any possible contribution to these masses under actual analysis conditions was evaluated 
by determining the absenee of minor isotope perturbations in the analyses of SRM 988, ${ }^{84} \mathrm{Sr}$ spike, which has ${ }^{86} \mathrm{Sr},{ }^{87} \mathrm{Sr}$, and ${ }^{88} \mathrm{Sr}$ atom fractions of $0.00059 \pm 0.00001,0.00010 \pm$ 0.00001 , and $0.00039 \pm 0.00001$, respectively [15]. Using this technique, any contribution to the ${ }^{85} \mathrm{Rb}$ mass position was observed to be $<10^{-15} \mathrm{~A}$, and a factor of $2.6 \mathrm{lcss}$ for the ${ }^{87} \mathrm{Rb}$ based on a natural ${ }^{85} \mathrm{Rb} /{ }^{27} \mathrm{Rb}$ ratio of 2.59 [9].

Details of the strontium isotopic analysis technique have been published [16]. Generally, the procedure consists of adding a drop of solution $\left[500 \mu \mathrm{g} \mathrm{Sr} / \mathrm{mL}\right.$ in $2 \%(\mathrm{~V} / \mathrm{V}) \mathrm{HNO}_{3}$ ] to each of two degassed 0.001 inch $\times 0.030$ inch regular rhenium filaments, drying under an infrared lamp and heating the resulting deposit with sequentially higher alternating currents to a final dull red heat. In the latter step the deposit "collapses" on the filament and undergoes an apparent reaction with the rhenium filament material to form a compound probably analogous to the $\mathrm{Ca}_{3} \mathrm{Re}_{2} \mathrm{O}_{9}$ and $\mathrm{CaReO}_{4}$ delected by electron diffraction earlier during $\mathrm{Ca}$ analyses [17].

This technique has becn used extensively in this laboratory for hundreds of strontium analyses, and has been adopted by several geological laboratories around the world. Experience has shown that inter-analysis variations in the unnormalized ${ }^{86} \mathrm{Sr} /{ }^{85} \mathrm{Sr}$ ratio can be held to $<0.05$ percent, relative, and usually substantially better using rigidly controlled analysis paramcters.

The two spectromelers used in these measurements were nominally identical $90^{\circ}$ sector, $30 \mathrm{~cm}$ radius of curvalure instruments equipped with thin lens Z-focusing ion sources and a conventional NBS-designed collector appropriatcly biased and baffled to minimize problems due to secondary particles [18]. Both measuring systems used Cary $401 \mathrm{MR}^{2}$ vibrating reed electrometers whosc attenuator resistors and amplifier linearities were calibrated relative to each other within \pm 0.01 pcrcent by placing precisely known relative voltages into the feedback loop of the electrometer. The $1 \mathrm{~V}$ analog output of the electrometer was digitizcd using two different systems: the instrument of operator I used a Hewlett-Packard $2212 \mathrm{~B}$ voltage-to-frequency convertor (full scale $=100 \mathrm{kHz}$ ) coupled to a high speed ATEC scaler; opcrator ll's instrument used a Teledyne (4501A) voltage-to-frequency convertor unit in tandem with a high speed scaler of NBS design. Data acquisition and instrument control for both instruments were achieved with Hewlett-Packard $9830 \mathrm{~A}(\mathrm{~B})$ programmable calculators, using software developed in this laboratory. In the absence of a priority interrupt capability for the calculator, the software was arranged such that the data averaging and printing segment at the end of each peak top measurement was completed in time for the caleulator to be ready for the next data transmission sequence from the scaler-VFC unit.

\footnotetext{
2 Certain commereial equipment. instruments, or materials are identified in this paper to specify uslequately the experimental procedure. Sueh identificution does not imply recommendation or endorsement by the National Bureau of Standards nor does it imply that the materials or equipment identificd are necessurily the best available for the purpose.
}

In the proeess of thermally vaporizing and ionizing samples, a mass dependent isotopic diserimination occurs that produces an observed isotope ratio that is not eharaeteristic of the sample. This diserimination oecurs among sample loadings and during a sample analysis. To minimize any discrimination-induced skewing of the relative isotope ratios with respect to a common time base during an analysis, the isotope ratios were measured symmetrically with respeet to mass. Typieally, eaeh peak was monitored for 10 precisely timed $1 \mathrm{~s}$ integrations, and 8-10 s (30-60 s for the separated isotope mixtures) were allowed between signal integration periods to allow for the RC decay of the electrometer as well as for a settling time for the magnetic field. Normally 10 to 20 ratios were measured for each isotope per analysis.

\subsection{Purification of the Separated Isotopes}

To prepare accurate isotopic standards for strontium, it is necessary to know, as accurately as possible, the concentration of strontium in solutions of separated isotopes of strontium. To aecomplish this objective a purification method and an assay procedure were developed that enabled us to determine the concentration of strontium in a solution with an accuracy of \pm 0.01 percent.

Electromagnetically separated ${ }^{80} \mathrm{Sr}$ and ${ }^{88} \mathrm{Sr}$ isotopes in the form of strontium nitrate were obtained from the Nuclear Division of the Oak Ridge National Laboratory. The ${ }^{80} \mathrm{Sr}\left(\mathrm{NO}_{3}\right)_{2}$ was designatcd series 136801 and the ${ }^{8} \mathrm{Sr}\left(\mathrm{NO}_{3}\right)_{2}$ was designated series 137001. The certificates of analysis which accompanied each sample included a scmi-quantitative spectrographic analysis which showed that several impurity elements could be present at the 0.02 to 0.05 percent level.

To reduce those impurities to a level low enough so that they could not cause a significant error in the assay of strontium, the separated isotope samples were further purified. The purification procedure used was based on the relative insolubility of strontium nitrate in concentrated nitric acid. Only two elements, barium and lead, are known to co-preeipitate under this condition [19]. If a dilute nitric acid solution is evaporated, the nitric acid concentration increases until the azeotropic solution containing 68 percent $\mathrm{HNO}_{3}$ is reached [20]. In 68 percent $\mathrm{HNO}_{3}$ the solubility of strontium nitrate is almost zero [21] while the solubility of most cations except barium and lead is sufficient to keep them in solution [19]. Lead can be effieiently removed by anodic electrodeposition but barium is not separated and remains as an impurity in the strontium nitrate.

The effectiveness of the purifieation procedure described below was first tested by the purifieation of natural strontium nitrate which had been doped with $1000 \mathrm{ppm}$ eaeh of 30 common impurity elements.

The results of the analysis of this material by spark source and thermal isotope dilution mass spectronetry are shown in 
table 1. The methods of analysis are also deseribed below. Only sodium was detected at a concentration greater than 1 $\mu \mathrm{g} / \mathrm{g}$ while all of the other elements were at the sub-ppm level. Barium was not determined since the purification method would not remove it and a correction for its eoncentration in each separated isotope is necessary.

Each strontium separated isotope was purified as follows: The strontium nitrate, $\mathrm{Sr}\left(\mathrm{NO}_{3}\right)_{2}$, (about $5.0 \mathrm{~g}$ ) was transferred to a $100 \mathrm{~mL}$ Teflon-FEP beaker and dissolved in $50 \mathrm{~mL}$ of water. One $\mathrm{mL}$ of $1 \mathrm{~mol} / \mathrm{L}$ hydrochloric acid was added and the solution was heated at about $90{ }^{\circ} \mathrm{C}$ on a hot plate for two hours. The solution was filtered through a close-textured filter paper into a Teflon-FEP beaker. Five $\mathrm{mL}$ of high-purity nitric acid was added to the filtrate and the solution was heatcd to about $90^{\circ} \mathrm{C}$ on a hot plate. Strontium nitrate was crystallized by allowing the solution to evaporate until only about $3 \mathrm{~mL}$ of solution remained $\left(68 \% \mathrm{HNO}_{3}\right)$. The beaker and contents were allowed to cool to room tcmperature. The solution was

TABLE 1. Analysis of Purified Strontium

\begin{tabular}{|c|c|c|c|c|}
\hline Element & $\begin{array}{l}\text { Spike } \\
\text { Isolope }\end{array}$ & $\begin{array}{c}\text { Nalural } \\
\left.\mathrm{Sr} \mathrm{NO}_{*}\right)_{2} \\
\mu g / g\end{array}$ & $\begin{array}{c}{ }^{k 6} \mathrm{Sr}_{\mathrm{r}} \\
\mathrm{Sr}\left(\mathrm{NO}_{: 1}\right)_{2} \\
\mu \mathrm{g} / \mathrm{g}\end{array}$ & $\begin{array}{c}{ }^{\mathrm{N}} \mathrm{Sr}_{\mathrm{r}} \\
\mathrm{Sr}_{\mathrm{r}}\left(\mathrm{NO} \cdot \mathrm{l}_{2}\right. \\
\mu \mathrm{g} / \mathrm{g}\end{array}$ \\
\hline Ag & ${ }^{109} \mathrm{Ag}$ & $0.4^{4}$ & 0.03 & 0.1 \\
\hline $\mathrm{Al}$ & 26 & $0.4^{\mathrm{a}}$ & 0.1 & 0.5 \\
\hline As & $\mathrm{me}$ & $0.03^{a}$ & - & - \\
\hline $\mathrm{Ba}^{\prime \prime}$ & 1:5. $\mathrm{Ba}$ & - & 12.5 & 0.73 \\
\hline $\mathrm{Bi}$ & ${ }^{203} \mathrm{Tl}$ & $0.04^{4}$ & - & - \\
\hline $\mathrm{Ca}^{\mathrm{b}}$ & ${ }^{42} \mathrm{Ca}$ & $0.10^{\prime \prime}$ & 0.78 & 0.30 \\
\hline $\mathrm{Cd}$ & $\|$ 'Cd & $0.01^{\prime \prime}$ & 0.01 & 0.01 \\
\hline $\mathrm{Ce}$ & ${ }^{142} \mathrm{Ce}$ & $0.004^{a}$ & 0.02 & 0.2 \\
\hline $\mathrm{Co}_{0}$ & ${ }^{\infty}: 2 \mathrm{Ni}$ & $0.01^{\prime \prime}$ & - & - \\
\hline $\mathrm{Cr}_{\mathrm{r}}$ & ${ }^{53} \mathrm{Cr}$ & $0.05^{a}$ & 0.07 & 0.06 \\
\hline $\mathrm{Cu}$ & ${ }^{65} \mathrm{Cu}$ & $0.04^{a}$ & 0.30 & 0.2 \\
\hline $\mathrm{Fe}$ & $\therefore \mathrm{Fe}$ & $0.3^{4}$ & 0.54 & 1.2 \\
\hline $\mathrm{Ga}$ & ${ }^{n} \mathrm{Ga}$ & 0.02 & 0.01 & 0.01 \\
\hline In & ${ }^{11: 3} \mathbf{I n}$ & 0.01 & 0.01 & 0.01 \\
\hline $\mathbf{K}$ & ${ }^{41} \mathrm{~K}$ & $0.05^{n}$ & 0.2 & 0.4 \\
\hline $\mathrm{La}$ & ${ }^{142} \mathrm{Ce}$ & $0.02^{\prime \prime}$ & - & - \\
\hline $\mathrm{Mg}$ & ${ }^{20} \mathrm{Mg}$ & $0.2^{\star}$ & 0.06 & 0.1 \\
\hline Mn & ${ }^{n} \mathrm{Fe}$ & $0.04^{4}$ & - & - \\
\hline Mo & ${ }^{97} \mathrm{Mo}$ & $0.12^{\mathrm{a}}$ & 0.03 & 0.02 \\
\hline $\mathrm{Na}$ & ${ }^{4} \mathrm{~K}$ & $2^{a}$ & 0.7 & 0.7 \\
\hline Nd & ${ }^{145} \mathrm{Nd}$ & 0.1 & 0.01 & 0.03 \\
\hline $\mathrm{Ni}$ & ${ }^{6 \cdot 2} \mathrm{Nj}$ & $0.0 \mathrm{I}^{4}$ & 0.03 & 0.06 \\
\hline $\mathrm{Pb}^{\mathrm{L}}$ & ${ }^{21 / 6} \mathrm{~Pb}$ & $0.04^{4}$ & 0.13 & 0.06 \\
\hline $\mathrm{Sb}$ & ${ }^{117} \mathrm{Sn}$ & $0.1^{4}$ & & \\
\hline Se & R2Se & $0.01^{a}$ & 0.01 & 0.01 \\
\hline $\mathrm{Sn}$ & ${ }^{117} \mathrm{Sn}$ & $0.3^{a}$ & 0.1 & 0.1 \\
\hline $\mathrm{Te}$ & ${ }^{125} \mathrm{Te}$ & $0.1^{\mathrm{u}}$ & 0.05 & 0.08 \\
\hline $\mathrm{T}]$ & ${ }^{2 \alpha} \mathrm{Tl}$ & $0.05^{a}$ & 0.07 & 0.1 \\
\hline $\mathrm{Ti}$ & ${ }^{47} \mathrm{Ti}$ & $0.05^{a}$ & 0.02 & 0.06 \\
\hline $\mathrm{V}$ & ${ }^{53} \mathrm{Cr}$ & $0.01^{\star \prime}$ & 0.1 & 8.8 \\
\hline $\mathrm{Zn}_{\mathbf{n}}$ & ${ }^{67} \mathrm{Zn}$ & $0.03^{a}$ & & \\
\hline $\mathrm{Zr}$ & ${ }^{2} \mathrm{Zr}$ & 0.0021 & 0.01 & 0.01 \\
\hline
\end{tabular}

- Doped with $1000 \mu \mathrm{g} / \mathrm{g}$ of each element before purification.

"Analyzed by thermal ionization mass speetromctry. withdrawn from the crystals of strontium nitrate by using a plastic hypodermic syringe with a platinum needle. The crystals were washed twice with $1 \mathrm{~mL}$ portions of nitric aeid which were withdrawn in the same manner. The excess nitric acid was then removed by heating the beaker until the crystals were dry.

Lead was removed from the crystallized strontium nitrate by dissolving it in about $50 \mathrm{~mL}$ of water and electrodepositing overnight onto platinum wire eleetrodes at an applied voltage of $2.0 \mathrm{~V}$. Under those conditions, lead will deposit as $\mathrm{PbO}_{2}$ onto the anode.

Only a slight deposit $(<5 \mu \mathrm{g} \mathrm{Pb})$ was noted on the anode from the "Sr 86" solution but there was a heavy deposit on the anode from the "Sr 88" solution with considerable $\mathrm{PbO}_{2}$ on the bottom of the beaker. The "Sr 88 " solution was filtered thru acid washed close-textured filter paper. After the addition of $5 \mathrm{~mL}$ of nitric acid to each solution, strontium nitrate was recrystallized as described above and lead was removed by electrodeposition in the same manner. Only a faint deposit (about $1 \mu \mathrm{g}$ ) was noted on the anode from the "Sr 86" solution but onee again the deposit on the anode from the "Sr 88" was heavy and partieles of $\mathrm{PbO}_{2}$ were on the bottom of the beaker, necessitating filtration of the solution.

The eyele of crystallization and electrodeposition was repeated four times for the " $\mathrm{Sr} 88$ " solution until the anode showed no evidence of $\mathrm{PbO}_{2}$ after electrodeposition. (The total amount of lead from the "Sr 88" solution amounted to $0.1 \%$ of the starting weight of ${ }^{88} \mathrm{Sr}\left(\mathrm{NO}_{3}\right)_{2}$.)

The final solutions from the lead separations were evaporated to dryness and the salts were transferred to two platinum crueibles, dried, and weighed. Calculations based on the starting weights of ${ }^{86} \mathrm{Sr}\left(\mathrm{NO}_{3}\right)_{2}$ and ${ }^{88} \mathrm{Sr}\left(\mathrm{NO}_{3}\right)_{2}$ and the weights of the corresponding purified salt showed that about 99 percent of the strontium was recovered in each case.

The aeids and water used in those purifications were produced at NBS by sub-boiling distillation [22] and have been shown to be extremely low in trace cation contamination. Apparatus such as beakers and filters were cleaned with highpurity aeid before use.

\subsection{Analysis of Purified Strontium Separated Isotopes}

About $0.5 \mathrm{~g}$ samples of each purified strontium isotope as $\mathrm{Sr}\left(\mathrm{NO}_{3}\right)_{2}$ were dissolved in $10 \mathrm{~mL}$ of water in a Teflon beaker and spiked with $10^{-7} \mathrm{~g}$ of ${ }^{109} \mathrm{Ag},{ }^{111} \mathrm{Cd},{ }^{142} \mathrm{Ce},{ }^{53} \mathrm{Cr},{ }^{65} \mathrm{Cu}$, ${ }^{54} \mathrm{Fe},{ }^{71} \mathrm{Ga},{ }^{113} \mathrm{In},{ }^{26} \mathrm{Mg},{ }^{97} \mathrm{Mo},{ }^{145} \mathrm{Nd},{ }^{62} \mathrm{Ni},{ }^{82} \mathrm{Se},{ }^{117} \mathrm{Sn},{ }^{125} \mathrm{Te}$, ${ }^{47} \mathrm{Ti},{ }^{203} \mathrm{Tl},{ }^{67} \mathrm{Zn}$, and ${ }^{91} \mathrm{Zr}$. Each solution was treated as follows: $1 \mathrm{~mL}$ of nitric acid was added and the solution was evaporated until most of the strontium crystallized and about $0.5 \mathrm{~mL}$ of nitric acid remained. The nitric aeid was removed from the crystallized strontium nitrate with a polypropylene hypodermic syringe equipped with a platinum needle and transferred to a Teflon beaker. The crystals of $\mathrm{Sr}\left(\mathrm{NO}_{3}\right)_{2}$ were 
washed twice with $0.5 \mathrm{~mL}$ portions of nitric acid which were removed in the same manner and combined with the acid from the crystallization. This nitric acid was concentratcd to a small drop, evaporated to dryness on high purity gold wires, and analyzed by spark-source mass spectrometry. The results of this analysis are also shown in table $l$.

In addition to the spiked elements, a number of other elements were determined by comparison to spiked nuclides and assuming that the sensitivities of the natural element and spike nuclide are the same.

Three elements, $\mathrm{Ba}, \mathrm{Pb}$, and $\mathrm{Ca}$ were determined by thermal ionization mass spectrometry since they were not obtained from the spark source analysis. Barium and lead are cocrystallized with the $\mathrm{Sr}\left(\mathrm{NO}_{3}\right)_{2}$ and calcium could not be determined because of $\mathrm{Sr}$ interference $\left(M / Z=44\right.$ for $\left.{ }^{8} \mathrm{~S}_{\mathrm{r}}{ }^{+}+\right)$. About $0.2 \mathrm{~g}$ samples were spiked with ${ }^{206} \mathrm{~Pb},{ }^{42} \mathrm{Ca}$, and ${ }^{135} \mathrm{Ba}$. Calcium was separated in the same manner as the separation for the spark source analysis. Lead was separately clectrodeposited from a nitrate solution onto a platinum anode. Barium was separated by adding lead and co-precipitating it with lead chromate by the addition of ammonium chromate. The chromates were caught on a filter and dissolved with $1.5 \mathrm{~mol} /$ $\mathrm{L} \mathrm{HCl}$. Lead and chromate ions were removed by passing the solution through a strongly basie anion exchange column, and the barium was recovered by evaporation of the eluate. The concentration of each analyte was determined from isotope ratio measurements using thermal ionization mass spectrometry.

The results of these analyses are also shown in table 1. Barium, which was not removed by the purification, was determined to be $12.5 \mu \mathrm{g} / \mathrm{g}$ in the ${ }^{86} \mathrm{Sr}\left(\mathrm{NO}_{3}\right)_{2}$ and $0.73 \mu \mathrm{g} /$ $\mathrm{g}$ in the ${ }^{88} \mathrm{Sr}\left(\mathrm{NO}_{3}\right)_{2}$. This would cause an error of about 0.002 percent in the ${ }^{86} \mathrm{Sr}$ assay and $<0.001$ percent for the ${ }^{88} \mathrm{Sr}$ assay. Since these errors are not significant, corrections were not applied. No other element was found at a level high enough to cause a possible significant error in the assay procedure.

\subsection{Preparation and Assay of the Separated Isotopic Solutions}

The $4.3 \mathrm{~g}$ of purificd ${ }^{\mathrm{B}} \mathrm{Sr}\left(\mathrm{NO}_{3}\right)_{2}$ was dissolved in about 50 $\mathrm{mL}$ of $0.5 \mathrm{~mol} / \mathrm{L} \mathrm{HNO} \mathrm{H}_{3}$, transferred to a specially constructed and tared $500 \mathrm{~mL}$ quartz flask and diluted to about $500 \mathrm{~mL}$ with $0.5 \mathrm{~mol} / \mathrm{L} \mathrm{HNO}_{3}$. This flask was constructed from a 500 $\mathrm{mL}$ quartz flask by cutting the neck of the flask about $1 \mathrm{~cm}$ from the body and tooling the ncck for a number zero polycthylene stopper and standard aluminum serum eap.

The $4.3 \mathrm{~g}$ of purified ${ }^{88} \mathrm{Sr}\left(\mathrm{NO}_{3}\right)$ was also dissolved in about $50 \mathrm{~mL}$ of $0.5 \mathrm{~mol} / \mathrm{L} \mathrm{HNO}_{3}$, transferred to a speeially constructed $200 \mathrm{~mL}$ quartz flask and diluted to about $200 \mathrm{~mL}$ with $0.5 \mathrm{~mol} / \mathrm{L} \mathrm{HNO}_{3}$. This flask was constructed in the same manner as described for the $500 \mathrm{~mL}$ flask. The bottles and contents were weighed to $\pm 0.2 \mathrm{mg}$ and the preliminary stron- tium concentration was calculated. The solution of ${ }^{86} \mathrm{Sr}\left(\mathrm{NO}_{3}\right)_{2}$ was designated " $\mathrm{Sr} 86$ " and the solution of ${ }^{88} \mathrm{Sr}\left(\mathrm{NO}_{3}\right)_{2}$ was designated "SR 88 ".

Four weighed portions each containing about $1.6 \mathrm{mmol}$ of strontium $\left(\sim 16 \mathrm{~g}\right.$ each for the ${ }^{88} \mathrm{Sr}$ solution and $\sim 40 \mathrm{~g}$ each for the ${ }^{80} \mathrm{Sr}$ solution) were withdrawn from each separated isotope solution in the following manner: a $10-\mathrm{cm}$ platinum needle was inserted through a No. 0 polyethylene stopper which was used to replace the cap in the bottle. A $10-\mathrm{mL}$ polyethylene hypodermic syringe with the plunger covered with a thin sheet of Teflon was attached to the Kel-F hub of the needle and the desired amount of solution was withdrawn. The syringe was then disconnected from the hub and the tip was capped with a Kel-F cap. Any static charge that might be present on the plastic syringe was dissipated by wiping it with a damp lintless towel. The syringe and contents were weighed on a semimicrobalance to $\pm 0.02 \mathrm{mg}$. The solution was then delivered from the syringe into a $100 \mathrm{~mL}$ TeflonFEP beaker and the syringe was again capped, wiped, and weighed. The weight of the sample was determined from the weight of the syringe before and after delivery of the sample. Two assay samples were withdrawn from each solution before and after withdrawing the calibration samples to ensure that no change in concentration had occurred during this time interval (about $3 \mathrm{~h}$ ).

Each portion was then assayed as follows: $1 \mathrm{~mL}$ of perchloric acid was added and the solution was evaporated at low heal to fumes of $\mathrm{HClO}_{4}$. The solution was then cooled, taken up in a few $\mathrm{mL}$ of water, and again evaporated to fumcs of $\mathrm{HClO}_{4}$. This procedure was repeated and the excess perchloric acid was removed by evaporation. (This procedure converts $\mathrm{Sr}\left(\mathrm{NO}_{3}\right)_{2}$ to $\mathrm{Sr}\left(\mathrm{ClO}_{4}\right)_{2}$ and is necessary because nitrate causes significant errors in the determination of strontium as sulfate.)

The residue was taken up in $20 \mathrm{~mL}$ of water and heated. Fiftecn $\mathrm{mL}$ of warm $(1+99) \mathrm{H}_{2} \mathrm{SO}_{4}$ was added dropwise to the hot solution while swirling the beaker to precipitate $\mathrm{SrSO}_{n}$. The sulfuric acid was added at a rate that required about 15$20 \mathrm{~min}$ to complete the addition. The solution was heated at $80-90^{\circ} \mathrm{C}$ for $2 \mathrm{~h}$ and evaporated to about $15 \mathrm{~mL}$ of solution. Fifteen $\mathrm{mL}$ of 95 percent ethyl alcohol was added and mixed with the solution. After tightly covering the beaker with plastic film, it was allowed to stand overnight to complete the precipitation.

The solution was then filtered through a tared platinum Monroe crucible and the prccipitated strontium sulfate was caught on the platinum mat. Any $\mathrm{SrSO}_{4}$ adhering to the walls of the beaker was freed by scraping with a Teflon "policeman" and transferred to the crucible with a stream of 95 pcreent ethyl alcohol. The filtrate, washings, and Teflon "policeman" were transferred baek to the original beaker and reserved for the determination of dissolved and untransferred strontium. The crucible and contents were dried for $2 \mathrm{~h}$ at $105^{\circ} \mathrm{C}$, 
ignited at $800^{\circ} \mathrm{C}$ for $8 \mathrm{~h}$, cooled in a desiccator, transfcrred to the case of a micro-balance and allowed to stand for at least $2 \mathrm{~h}$. The crucible and contents were weighed on the micro-balance to $\pm 0.002 \mathrm{mg}$. A buoyancy correction for platinum crucibles was made by averaging three empty tare crucibles. (The drying, cooling, and weighing were repeatcd to insure constant weight.) The air weight of the $\mathrm{SrSO}_{4}$ was then determined and converted to vacuum weight using 3.92 for the density of ${ }^{86} \mathrm{SrSO}_{4}$ and 3.97 for the density of ${ }^{8} \mathrm{SrSO}_{4}$. These densities were calculated by assuming that they were proportional to the density of natural $\mathrm{SrSO}_{4}, 3.96$ in the same relationship as their molecular weight. The vacuum weight of the strontium sulfate was converted to millimoles of strontium using a calculated atomic weight for strontium and the 1977 atomic weight values for sulfur and oxygen. The formula weights used were 182.0066 for the ${ }^{86} \mathrm{SrSO}_{4}$ and 183.9612 for the ${ }^{88} \mathrm{SrSO}_{4}$.

To determine the soluble and untransferred strontium, the filtrate and washings which had been reserved in the original beaker wcre spiked with about $1.5 \mathrm{mmol}$ of ${ }^{84} \mathrm{~S} r$. The ${ }^{84} \mathrm{~S}_{r}$ was NBS SRM 988, Strontium 84 Spike Assay and Isotopic Solution Standard. The solution was heated and concentrated to about $10 \mathrm{~mL}$ to remove ethyl alcohol. Fifteen $\mathrm{mL}$ of $\mathrm{HCl}$ and $5 \mathrm{~mL}$ of $(1+99) \mathrm{H}_{2} \mathrm{SO}_{4}$ were added, and the solution was diluted to $100 \mathrm{~mL}$ with water. The solution was then heated for two hours to ensure equilibration of the natural and spike strontium. The solution was evaporated to fumes of perchloric acid and then the heat was increased to fumes of sulfuric acid. After cooling, the residue was taken up in $15 \mathrm{~mL}$ of water and passed through a cation exchangc column, eontaining $5 \mathrm{~mL}$ of $A G 50 \mathrm{~W} \times 8$, resin. The column was then washed with $50 \mathrm{~mL}$ of $0.5 \mathrm{~mol} / \mathrm{L} \mathrm{HCl}$ and the $\mathrm{Sr}$ was eluted with $25 \mathrm{~mL}$ of $6 \mathrm{~mol} / \mathrm{L} \mathrm{HCl}$. This solution was evaporated to dryness. The residue was converted to the nitrate by the addition of a few drops of nitric acid followed by evaporation. The residue was taken up and the $84 / 86$ or $84 / 88$ ratio was determined by thermal ionization mass spectrometry. The $\mathrm{Sr}$ found as $\mathrm{mmol} \mathrm{S}_{\mathrm{r}}$ was added to the strontium from the gravimetrie determination to yield the total strontium in the sample.

This method of determining the strontium was first tested on solutions containing known amounts of strontium. Ten solutions were prepared from high purity strontium carbonate. The material used was SRM 987, Strontium Carbonate, which has an assay value of $99.98 \pm 0.02$ pereent. The solutions were prepared in the approximate concentration range of 0.10 to $0.12 \mathrm{mmol} / \mathrm{g}$. Four samples containing from 1.50 to 1.79 mmol were withdrawn from each solution and the strontium was determined as describcd above. Comparison of the calculated to measurcd concentration detected a small positive bias of about 0.01 percent, but this would have a negligible effeet on ratios.

The results of the assay of the separated isotope solutions are shown in table 2. Pooling the results of the separated isotope solutions and the ten sets described above, yields an uncertainty of $0.119 \times 10^{-5} \mathrm{mmol} / \mathrm{g}$ for the concentration of the "Sr 86 " solution and $0.297 \times 10^{-5} \mathrm{mmol} / \mathrm{g}$ for the eoncentration of the "Sr 88 " solution.

\subsection{Preparation of Calibration Samples}

Six calibration samples were prepared by mixing weighed portions of " $\mathrm{Sr} 86$ " and the "Sr 88 " solutions to produee 88/ 86 ratios, ranging from 8 to 0.7 . Four of the calibration samples were within a few percent of the natural $88 / 86$ ratio of 8.38 and two bracketed the natural $87 / 86$ ratio of 0.71 . The portions were withdrawn from the flasks and weighed in the manner previously deseribed for assay of the solution. To eliminate any possibility of change in the concentration of the isotope solution with time, the portions for the calibration samples were withdrawn from the flasks between the samples taken for assay over a period of about $6 \mathrm{~h}$.

TADLE 2. Assay of Strontium Separated /solope Solutions Separate I

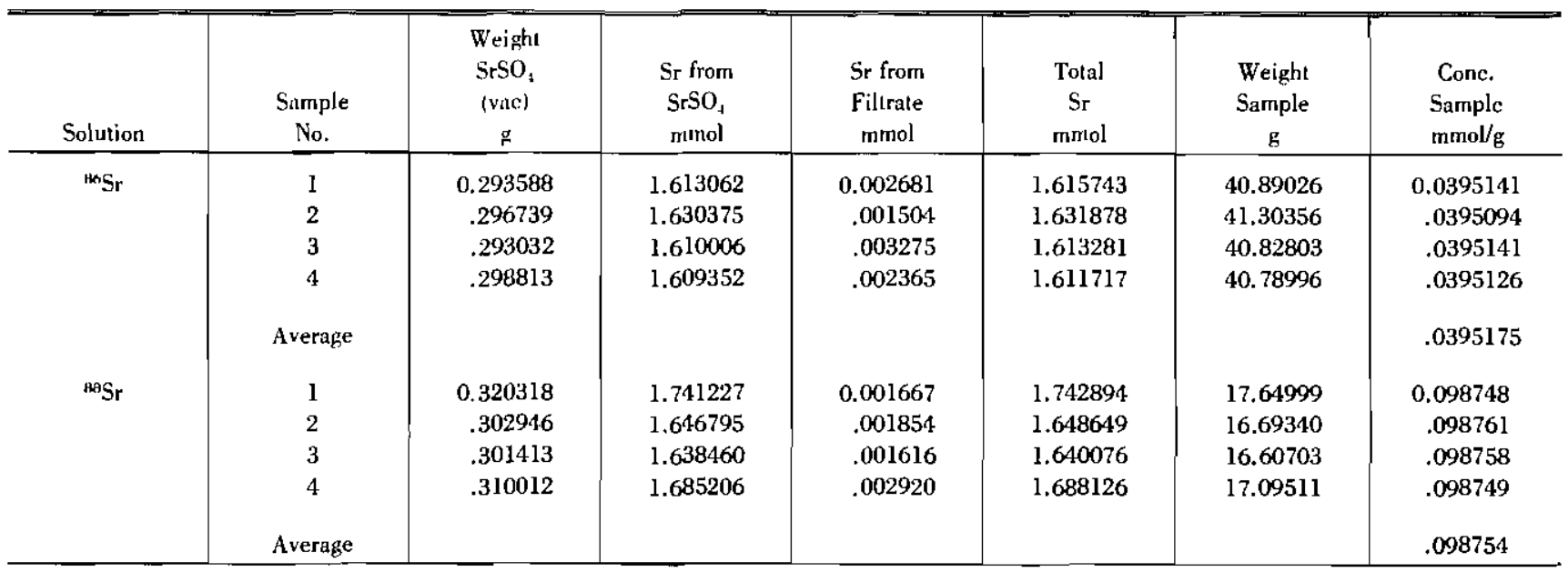


Table 3 shows the eomposition of these ealibration samples. The isotope ratio of eaeh calibration sample was ealculated from the isotopie analysis of the separated isotopes and from the mmols of strontium from each separated isotope solution as determined from the assay and weight of solution taken.

Each calibration sample was thoroughly mixed and evaporated to dryness at low heat on a hot plate. The ealibration samples were taken up in $(1+49)$ nitric aeid so that $1 \mathrm{~mL}$ of solution contained $500 \mu \mathrm{g}$ of strontium.

\section{Results and Discussion}

Isotopie compositions of the purified ${ }^{86} \mathrm{Sr}$ and ${ }^{88} \mathrm{Sr}$ were eaeh measured by Operator \#I, using 7-10 sample analyses for each separated isotope. Before and after eaeh set of separated isotope analyses, the ion source was removed from the instrument and metieulously cleaned. Prior to each set of separated isotope analyses, the source was carefully checked to insure the absence of any cross contamination. The results of the measurement of the separated isotope solutions are shown in table 4.

The six synthetic isotope mixes were seleeted randomly and measured two or three times by each operator for its ${ }^{88} \mathrm{Sr} /$ ${ }^{86}$ Sr ratio. SRM 987 was analyzed after every two mixes, and the average of these SRM analyses provided the data used in the final eomputation of the absolute abundanee ratios of the reference sample.

The results of the measurements of the separated isotope mixtures as well as the eorrection factors for each operator are shown in table 5 .

In Table 6 are shown ratios for the reference material (SRM 987-Strontium Carbonate) for eaeh operator.

The calculations of the atomic weight of the reference sample of strontium are shown in table 7. The value ealeulated is only applicable to the reference material (SRM 987) sinee samples in nature with large variations in the ${ }^{87} \mathrm{Sr} /{ }^{16} \mathrm{Sr}$ ratios

TABLE 3. Isotopic Composition of Calibration Samples

\begin{tabular}{|c|c|c|c|c|c|c|c|c|}
\hline $\begin{array}{c}\text { Solution } \\
\text { No. }\end{array}$ & $\begin{array}{l}\text { Isotope } \\
\text { Solution }\end{array}$ & $\begin{array}{c}\text { Weight } \\
\text { Solution } \\
\text { g }\end{array}$ & $\begin{array}{c}\text { Sr } \\
\text { from } \\
\text { Solution } \\
\text { mmol } \\
\end{array}$ & $\begin{array}{c}{ }^{\text {HoS }} \text { r } \\
\text { from } \\
\text { Solution } \\
\text { mmol } \\
\end{array}$ & 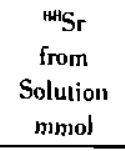 & $\begin{array}{c}\text { Total } \\
\text { nosr } \\
\text { Solution } \\
\text { mmol } \\
\end{array}$ & $\begin{array}{c}\text { Total } \\
\text { Solution } \\
\text { mmol } \\
\text { molion }\end{array}$ & $\begin{array}{c}\text { Ratio } \\
88 / 86 \\
\text { Solution }\end{array}$ \\
\hline 1 & "Sr 86" & 5.05855 & 0.199876 & 0.195191 & 0.003349 & & & \\
\hline$\cdot$ & "Sr 88" & 16.28401 & 1.608108 & .000741 & 1.605506 & 0.195932 & 1.608855 & 8.211280 \\
\hline \multirow[t]{2}{*}{2} & "Sr 86" & 4.94747 & 0.195487 & 190905 & 0.003276 & & & \\
\hline & "Sr 88" & 16.45020 & 1.594893 & .000735 & 1.592313 & .191640 & 1.595589 & 8.325967 \\
\hline \multirow[t]{2}{*}{3} & "Sr B6" & 4.98057 & 0.196795 & .192182 & 0.003298 & & & \\
\hline & "Sr 88" & 16.50848 & 1.630275 & .000751 & 1.627637 & .192934 & 1.630935 & 8.453349 \\
\hline \multirow[t]{2}{*}{4} & "Sr 86" & 5.20231 & 0.205557 & .200738 & 0.003144 & & & \\
\hline & "Sr 88" & 17.41636 & 1.719931 & .000793 & 1.717149 & .201531 & 1.720593 & 8.537609 \\
\hline \multirow[t]{2}{*}{5} & "Sr 86" & 17.91602 & 1.707908 & .691315 & 0.011862 & & & \\
\hline & "Sr 88" & 5.02571 & 0.496308 & .000229 & 0.495505 & .691543 & 0.507367 & 0.733673 \\
\hline \multirow[t]{2}{*}{6} & "Sr B6" & 18.24981 & 0.721097 & .709195 & 0.012083 & & & \\
\hline & "Sr 88" & 4.89190 & 0.483094 & .000223 & 0.482312 & .704417 & .494395 & .7018501 \\
\hline
\end{tabular}

TABlE 4. Isotopic Composition of Separated Strontium Isotopes Used in Calibration Samples

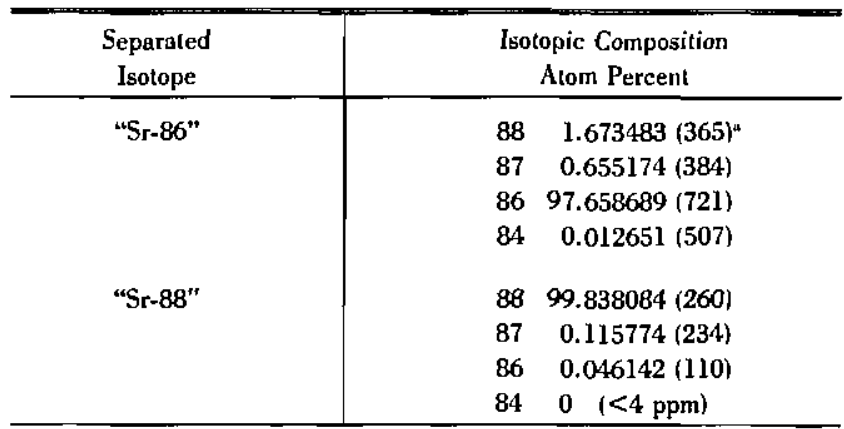

- Numbers in brackets are the errors (95\% confidence limits) on the last digits of the numbers given. 
are known. Subsequent to the Faraday cage measurements described here, high sensitivity pulse counting mcasurcments in this laboratory have indicated the possibility of sporadic backgrounds at the $M / Z=86$ position of $\sim 10^{-16} \mathrm{~A}$. Although the background has tentatively been identified as a hydrocarbon residue resulting from previous exposure to resin beads in the specific pulse eounting system (not either instrument used in the Sr measurements), an extra allowanee of 0.01 percent has been added to the systematie error of the ${ }^{88} \mathrm{Sr} /{ }^{36} \mathrm{Sr}$ and ${ }^{87} \mathrm{Sr} /{ }^{36} \mathrm{~S}$ r ratios as a precaution. ${ }^{3}$

It should be noted that the value of the ${ }^{86} \mathrm{Sr} /{ }^{88} \mathrm{Sr}$ ratio of 0.119351 is very close to the less precise value of 0.1194 universally used. The continued use of this historical value seems justified cxcept where the very highest accuracy is required.

\footnotetext{
${ }^{3}$ Reeently published research [23] has demonstraled the formation of molecular parent and decomposition ions from qualentary ammonium salıs (e.g., $M / Z=86=$ $\mathrm{C}_{5} \mathrm{H}_{12} \mathrm{~N}^{+}$) in a conventional thermal ionization source. These dala support the observation that exposure of the pulse counling mass spectrometer to anion exehange resin beads (quatemary ammonium salts) was the probable cause for background peaks in the strontium mass region for that apecific unass spectromeler. Since: (a) the mass spectrometers used for strontium were never exposed to these resin beads; (b) all oller measurement evidence in the strontium data do not reflect a statislically significan background; (c) no higher intensity molecular ion peaks were observed that one would expect to accompany those of the strontium mass regiou, we believe tho isolope ratio dala for SRM 987 to be free of syslernatic bjas well within the slated error limits.
}

TABLE 5. Determination of Mass Spectrometer Bias

\begin{tabular}{|c|c|c|c|c|c|}
\hline \multirow{2}{*}{$\begin{array}{c}\text { Calibration } \\
\text { Sample } \\
\text { No. } \\
\end{array}$} & \multicolumn{3}{|c|}{ 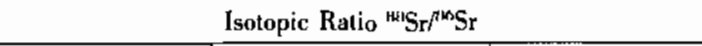 } & \multicolumn{2}{|c|}{ Correction Faetor } \\
\hline & Calculated & Operator I & Operator II & Operator I & Operator II \\
\hline 1 & 8.211280 & 8. 200908 & 8. 197613 & 1.001265 & 1.001667 \\
\hline 2 & 8.325967 & 8.315727 & 8.315177 & 1.001231 & 1.001298 \\
\hline 3 & 8.453349 & 8.442254 & 8.443429 & 1.001314 & 1.001175 \\
\hline 4 & 8.537609 & 8.527686 & 8.527326 & 1.001164 & 1.001201 \\
\hline 5 & 0.733673 & 0.732628 & 0.732525 & 1.001426 & 1.001567 \\
\hline 6 & .701850 & .700835 & .700891 & 1.001448 & 1.001368 \\
\hline
\end{tabular}

TABLE 6. Isolopic Ratios of SRM 987, SrCO:

\begin{tabular}{|c|c|c|c|c|c|}
\hline Ratio & Operator 1 & Operator 2 & Average Ratio" & $\begin{array}{l}\text { Correction } \\
\text { Factor }\end{array}$ & $\begin{array}{c}\text { Correcled } \\
\text { Ratio }\end{array}$ \\
\hline 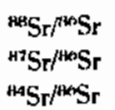 & $\begin{array}{l}8.3678911 \\
0.7099313 \\
0.0566361\end{array}$ & $\begin{array}{l}8.36689550 \\
0.7098806 \\
0.0566166\end{array}$ & $\begin{array}{l}8.3673671 \\
0.7098619 \\
0.0566253\end{array}$ & $\begin{array}{l}1.0013439 \\
1.0006719 \\
0.9986579\end{array}$ & $\begin{array}{l}8.378612 \\
0.7103389 \\
0.05654927\end{array}$ \\
\hline
\end{tabular}

"Because no statislically significant differences were found between the data of operators 1 and 2 they were combincd into a single sel for the calculalion of average ratio, correction factor, and corrected ratio. The appropriate error limits are given in Table 7.

TABle 7. Atomic Weight, Atom Percent, and Isotopic Ratios of Strontium (corrected for systematic errors)

\begin{tabular}{|c|c|c|c|c|c|c|}
\hline & Value & $\begin{array}{c}\text { Total } \\
\text { Uncertainty }\end{array}$ & $\begin{array}{l}\text { Due to } \\
\text { Error in } \\
\text { Calibration } \\
\text { Factor }\end{array}$ & $\begin{array}{c}\text { Duc to } \\
\text { Error in } \\
\text { Ratio } \\
\text { Determinalion }\end{array}$ & $\begin{array}{c}\text { Due to } \\
\text { Systematic } \\
\text { Error in } \\
\text { Determination }\end{array}$ & $\begin{array}{l}\text { Due to } \\
\text { Error in } \\
\text { Nuclidic } \\
\text { Masses of } \\
\text { Isotopes }\end{array}$ \\
\hline Atomic Weighı & 87.616814 & 0.000117 & 0.0000477 & 0.0000266 & 0.0000397 & 0.0000029 \\
\hline \multicolumn{7}{|l|}{ Atom Percenl } \\
\hline Sr-84 & 0.55738 & 0.00155 & 0.000211 & 0.000412 & 0.00093 & \\
\hline Sr-86 & 9.85659 & .00337 & .001718 & .000724 & .00093 & \\
\hline Sr-87 & 7.00152 & .00263 & .000506 & .000862 & .00126 & \\
\hline Sr-88 & 82.58451 & .00657 & .002435 & .001458 & .00268 & \\
\hline \multicolumn{7}{|l|}{ Isotopic Ratios } \\
\hline $84 / 86$ & 0.056549 & 0.000143 & 0.0000115 & 0.0000420 & 0.00009 & \\
\hline $87 / 86$ & .710339 & .000261 & .0000725 & .0000760 & .00007 & \\
\hline $88 / 86$ & 8.37861 & .003248 & .0017070 & .0007409 & .00080 & \\
\hline
\end{tabular}


The authors are indebted to Drs. John Orban and Keith Eberhardt for the statistical analysis of the experimental data and to Mr. W. A. Bowman for assistance with instrument maintenance. We also thank Mrs. Joy Shoemaker and Teresa Sperow for their painstaking typing of the manuscript.

\section{References}

[1] Shields, W. R., Garner, E. L., and Dibeler, V. H., Absolute Isotopic Abundance of Terrestrial Silver, J. Res. Nat. Bur. Stand. (U.S.) 66A (Phys. and Chem.) 1 (1962).

[2] Shields, W. R., Murphy, T. J.. Garner, E. L., and Dibeler. V. H., Absolute Isotopic Abundance Ratio and the Atomic Weight of Chlorine. J. Am. Chem. Soc., 84, 1519 (1962).

[3] Shields, W. R., Murphy, T. J.. and Garner. E. L., Absolute Isotopic Abundance Ratio and the Atomic Weight of a Reference Sample of Copper, J. Res. Nat. Bur. Stand. (U.S.) 68A (Phys. and Chem.) 589 (1964).

[1] Catanzaro, E. J., Murphy, T. J., Gamer, E. L., and Shields, W. R., Absolute Isotopic Abundance Ratio and the Atomic Weight of Bromine. J. Res. Nal. Bur. Stand. (U.S.) 68A (Phys. and Chem.) 593 (1964).

[5] Shields, W. R., Murphy, T. J., Catanzaro, E. J., and Gamer, E. L.. Absolute lsolopic Abundance Ratio and the Alomic Weight of a Reference Sample of Chromium, J. Res. Nat. Bur. Stand. (U.S.) 70A (Phys. and Chem.) 193 (1966).

[6] Catanzaro. E. J. Murphy. T. J., Garner. E. L., and Shields. W. R., Absolute lsotopic Abundance Ratios and Atomic Weight of Magnesium, J. Res. Nat. Bur. Stand. (U.S.) 70A (Phys. and Chem.) 453 (1966).

[7] Catanzaro, E. J.. Murphy, T. J.. Shields. W. R., and Garner, E. L., Absolute Isotopic Abundance Ratios of Common. Equal-Atom. and Radiogenic Lead Isotopic Standards. J. Res. Nat. Bur. Stand. (U.S.) 72A (Phys. and Chem.) 261 (1968).

[8] Catanzaro, E. J., Champion, C. E., Gamer. E. L., Marinenko. G.. Sappenfield, K. M., and Shields. W. R., Nat. Bur. Stand. (U.S.) Spec. Publ. 26017, 70 pages (Feb. 1969 ).

[9] Catanzaro. E. J.. Murphy. T. J.. Gamer, E. L., and Shields. W. R., Absolute lsotopic Abundance Ratio and Atomic Weight of Terrestrial Rubidium. J. Res. Nat. Bur. Stand. (U.S.) 73A (Phys. and Chem.) 3110691.
[10] Gramlich, J. W., Murphy, T. J., Garner, E. L., and Shields, W. R., Absolute Isotopic Abundance Ratio and Atomic Weight of a Reference Sample of Rhenium, J. Res. Nat. Bur. Stand. (U.S.) 77A (Phys. and Chem.) 691 (1973).

[1I] Barnes, I. L., Moore. L. J., Machlan, L. A., Murphy, T. J., and Shields, W. R., Absolute Isotopic Abundance Ratios and the Alomic Weight of a Reference Sample of Silicon, J. Res. NBS (U.S.), 79A (Phys. and Chem.), 727-740 (1975).

[12] Garner, E. L., Murphy, T. J., Gramlich, J. W., Paulsen, P. J., and Barnes, 1. L., Absolute Isotopic Abundance Ratios and the Atomic Weight of a Reference Sample of Potassium, J. Res. Nat. Bur. Stand. (U.S.) 79A (Phys. and Chem.) 713 (1975).

[13] Dunstan, L. P., Gramlich, J. W., Bames, I. L.. and Purdy, W. C.. Absolute Isotopic Abundance and the Atomic Weight of a Reference Sample of Thallium, J. Res. Nat. Bur. Stand. IU.S.) 85 (Phys. and Chem.) 1-10 (1980).

[14] Nier, A. O., The Isotopic Constitution of Strontium, Barium. Bismuth, Thallium, and Mercury, Phys. Rev. 5, 275-278 (1938).

[15] Certificate of Analysis, SRM 988. Office of Standard Reference Materials, NBS, Washington, D.C. 20234.

[16] Moore, L. J., Moody, J. R., Barnes, I. L.. Gramlich, J. W., Murphy, T. J., Paulsen, P. J., and Shields, W. R., Trace Determination of Rubidium and Strontium in Silicate Glass Standard Reference Materials, Anal. Chem. 45, 2384-2387 (1973).

[17] Moore, L. J., Machlan, L. A. , High Accuracy Determination of Calcium in Blood Serum by Isotope Dilution Mass Spectrometry, Anal. Chem. 44, 2291-2296 (1972).

[18] Shields, W. R. (ed.). Nat. Bur. Stand. (U.S.). Tech. Note, 277, 99 (July 1966).

[19] Willand, H. W.. and Goodspeed. E. W.. Separations of Strontium, Barium, and Lead from Calcium and Other Metals, Ind. and Eng. Chem., Anal. Ed.. 8, 414-418 (1936).

[20] Roscoe, H. E., On the Composition of the Aqueous Acids of Constant Boiling Point, J. Chem. Soc., 13, 146-154 (1860).

[21] Sieverts, A., and Petzold, W. Z., Das System Strontiumnitnat-Salpetersäure-Wasser, Anorg. Chem., 214, 27-32 (1933).

[22] Kuehner, E. C., Alvarez. R. Paulsen, P. J., Murphy, T. J., Production and Analysis of Special High Purity Acids Purified by Sub-Boiling Distillation. Anal. Chem., 44, 2050-2056 (1972).

[23] Cotter, R. J., Yergey, A. L., Thermal Desorption of Quatemary Ammonium Cations, J. Am. Chem. Soc. 103, 1596-1598 (1981). 